\title{
A Revised Structure and Assigned Absolute Configuration of Theissenolactone A
}

\author{
Melissa M. Cadelis ${ }^{1,2, *} \mathbb{0}$, Soeren Geese ${ }^{2}$, Lauren Gris ${ }^{3}$, Bevan S. Weir ${ }^{4}$, Brent R. Copp ${ }^{1,+}+(\mathbb{C}$ and \\ Siouxsie Wiles $2, *,+(\mathbb{D}$ \\ 1 School of Chemical Sciences, University of Auckland, Private Bag 92019, Auckland 1142, New Zealand; \\ b.copp@auckland.ac.nz \\ 2 Bioluminescent Superbugs Lab, School of Medical Sciences, University of Auckland, Private Bag 92019, \\ Auckland 1142, New Zealand; s.geese@auckland.ac.nz \\ 3 Department of Fine and Industrial Organic Chemistry, SIGMA Clermont, Campus des Cézeaux, CS 20265, \\ 63178 Aubière, France; lauren.gris85@laposte.net \\ 4 Manaaki Whenua-Landcare Research, Private Bag 92170, Auckland 1142, New Zealand; \\ WeirB@landcareresearch.co.nz \\ * Correspondence: m.cadelis@auckland.ac.nz (M.M.C.); s.wiles@auckland.ac.nz (S.W.) \\ + These authors contributed equally to this work.
}

Received: 28 September 2020; Accepted: 16 October 2020; Published: 20 October 2020

check for updates

\begin{abstract}
Antimicrobial bioassay-guided fractionation of Microcera larvarum led to the isolation of a $\gamma$-lactone with a furo[3,4-b]pyran-5-one bicyclic ring system (1) and three known compounds, (3S,4R)-4-hydroxymellein (2), (3S,4S)-4-hydroxymellein (3) and 7-hydroxy-3(1-hydroxyethyl)isobenzofuran-1(3H)-one (4). Structure elucidation was conducted by NMR spectroscopic methods. Absolute configuration of $1(2 R, 3 S, 5 S, 7 S, 8 R)$ was established using the chiral derivatizing agent MPA and was fully supported by calculated specific rotation and ECD spectra. The spectroscopic data observed for $\mathbf{1}$ were identical to those previously reported for theissenolactone A (7), necessitating a correction of the latter (from C-5/C-8 trans ring fusion to cis). Compounds 1-4 were evaluated for antimicrobial activity against a panel of pathogens.
\end{abstract}

Keywords: fungi; antimicrobial; lactone; natural product

\section{Introduction}

Most antibiotics used in the clinic today come from soil microbes, beginning with the discovery of penicillin from the fungus Penicillium. Aotearoa New Zealand has a treasure trove of unique fungi that have not been exhaustively searched for new antibiotics. Thus, we have recently begun investigating fungal isolates from the International Collection of Microorganisms from Plants (ICMP), which contains cultures derived from plants and soil from Aotearoa New Zealand and the South Pacific, in pursuit of novel antimicrobials. Bioassay-guided investigation of the ascomycete fungus Microcera larvarum led to the isolation of a $\gamma$-lactone with a furo[3,4- $b]$ pyran-5-one bicyclic ring system (1) and three other known natural products including two hydroxymelleins (2 and 3) and an isobenzofuranone (4) (Figure 1). 
<smiles>CC=C[C@H]1O[C@@H]2[C@H](C[C@H]1O)C(=O)O[C@@H]2C</smiles>

1<smiles>C[C@@H]1OC(=O)c2c(O)cccc2[C@@H]1O</smiles>

2<smiles>C[C@@H]1OC(=O)c2c(O)cccc2[C@H]1O</smiles>

3<smiles>CC(O)[C@H]1OC(=O)c2c(O)cccc21</smiles>

4

Figure 1. Structures of natural products 1-4.

Literature search of $\gamma$-lactones with the same furo[3,4-b]pyran-5-one bicyclic ring system as 1 identified three isomeric compounds, 5-7 (Figure 2), previously reported from fungi. The planar structure of $\mathbf{1}$ was first reported by Gao et al. as synthetic intermediates 5 and $\mathbf{6}$ in their study of a related natural product, TAN-2483A [1]. A third example of this planar structure is that of theissenolactone A (7), reported by Liang et al. from the fermentation broth of Theissenia cinerea 89,091,602 [2]. Of note in the case of 7 is the reported C-5/C-8 trans ring fusion. The relative configuration of 5-7 have been reported while the absolute configuration has yet to be established.<smiles>CC=C[C@H]1O[C@@H]2[C@H](C[C@H]1O)C(=O)O[C@@H]2C</smiles>

5<smiles>[2H]C=C[C@@H]1O[C@]2(C)[C@H](C[C@@H]1O)C(=O)O[C@@H]2C</smiles>

6<smiles>CC=C[C@H]1O[C@H]2[C@@H](C)OC(=O)[C@@H]2C[C@H]1O</smiles>

proposed structure of theissenolactone A (7)<smiles>CC=C[C@H]1O[C@H]2[C@H](C[C@@H]1O)C(=O)O[C@@H]2C=CI</smiles>

trans-dihydrowaol A (8)

Figure 2. Structures of reported $\gamma$-lactones 5-8.

Structure verification of natural products 1-4 was established by spectroscopic methods while the absolute configuration of $\mathbf{1}$ was assigned by use of a chiral derivatizing agent and further supported by computational chemistry. Direct comparison of the spectroscopic data of 1 and 7 [2] showed that they were identical. Herein, we report the revised structure of theissenolactone A from $\mathbf{7}$ to $\mathbf{1}$ and establishment of the absolute configuration of this compound.

\section{Results and Discussion}

Freeze-dried agar plates inoculated with Microcera larvarum were extracted using a combination of methanol and dichloromethane. Initial fractionation of the crude organic extract was conducted by $\mathrm{C}_{8}$ reversed-phased column chromatography, eluting with gradient $\mathrm{H}_{2} \mathrm{O} / \mathrm{MeOH}$ which afforded five fractions (F1-F5). Antimicrobial testing of F1-F5 against Staphylococcus aureus ATCC 29,213 and Escherichia coli ATCC 25,922 identified activity for F3 and F4 against the latter at minimum inhibitory concentrations (MIC) of 1 and $0.5 \mathrm{mg} / \mathrm{mL}$, respectively. In addition, $\mathrm{F} 4$ also exhibited non-bactericidal activity against $S$. aureus at MIC $1 \mathrm{mg} / \mathrm{mL}$. Further purification of F2-F4 by a combination of Diol-bonded silica and silica gel column chromatography led to the isolation of compounds $\mathbf{1}-\mathbf{4}$.

Compound 1 was isolated as a white solid. High resolution ESI mass spectrometry identified a sodiated adduct of $m / z 235.0940[\mathrm{M}+\mathrm{Na}]^{+}$which was consistent with the molecular formula $\mathrm{C}_{11} \mathrm{H}_{16} \mathrm{O}_{4}$ (Figure S10). Analysis of the ${ }^{1} \mathrm{H}-\mathrm{NMR}$ spectrum in $\mathrm{CDCl}_{3}$ (Table 1, Figure S4) identified the presence of two trans olefinic protons $\left(\delta_{\mathrm{H}} 5.89(\mathrm{dq}, J=15.5,6.6 \mathrm{~Hz}, \mathrm{H}-11)\right.$ and $5.42(\mathrm{ddq}, J=15.5,7.7,1.6 \mathrm{~Hz}$, $\mathrm{H}-10)$ ), four oxymethines $\left(\delta_{\mathrm{H}} 4.58(\mathrm{q}, J=7.0 \mathrm{~Hz}, \mathrm{H}-7), 4.04(\mathrm{~d}, J=4.1 \mathrm{~Hz}, \mathrm{H}-8), 3.45(\mathrm{dd}, J=9.0,7.7 \mathrm{~Hz}\right.$, $\mathrm{H}-2)$ and $3.34(\mathrm{ddd}, J=11.0,9.0,5.0 \mathrm{~Hz}, \mathrm{H}-3))$, a methine $\left(\delta_{\mathrm{H}} 2.90(\mathrm{ddd}, J=6.1,4.1,2.0 \mathrm{~Hz}, \mathrm{H}-5)\right)$, a diastereotopic methylene $\left(\delta_{\mathrm{H}} 2.64\left(\mathrm{ddd}, J=13.4,5.0,2.0 \mathrm{~Hz}, \mathrm{H}_{2}-4_{\mathrm{A}}\right)\right.$ and $1.73(\mathrm{ddd}, J=13.4,11.0$, $\left.\left.6.1 \mathrm{~Hz}, \mathrm{H}_{2}-4_{\mathrm{B}}\right)\right)$ and two methyl groups $\left(\delta_{\mathrm{H}} 1.77\left(\mathrm{dd}, J=6.6,1.6 \mathrm{~Hz}, \mathrm{H}_{3}-12\right)\right.$ and $1.33(\mathrm{~d}, J=7.0 \mathrm{~Hz}$, $\left.\mathrm{H}_{3}-9\right)$ ). The ${ }^{13} \mathrm{C}-\mathrm{NMR}$ data (Table 2, Figure S5) revealed 11 carbon signals, indicative of one carbonyl 
$\left(\delta_{C} 176.0(\mathrm{C}-6)\right)$, two olefinic $\left(\delta_{C} 127.8(\mathrm{C}-10)\right.$ and $\left.133.0(\mathrm{C}-11)\right)$, four oxymethine $\left(\delta_{C} 66.6(\mathrm{C}-3), 77.7\right.$ (C-8), $80.5(C-7), 81.5(C-2))$, one methine $\left(\delta_{C} 39.0(C-5)\right)$, one methylene $\left(\delta_{C} 28.3(C-4)\right)$ and two methyl carbons $\left(\delta_{\mathrm{C}} 17.6(\mathrm{C}-9)\right.$ and $\left.18.2(\mathrm{C}-12)\right)$. The COSY spectrum established the connectivity order as $\mathrm{H}_{3}-12$ to $\mathrm{H}-11$ to $\mathrm{H}-10$ to $\mathrm{H}-2$ to $\mathrm{H}-3$ to $\mathrm{H}_{2}-4$ to $\mathrm{H}-5$ to $\mathrm{H}-8$ to $\mathrm{H}-7$ to $\mathrm{H}_{3}-9$ (Figure 3). Key HMBC correlations were observed between $\mathrm{H}-7$ and $\mathrm{C}-6, \mathrm{H}-8$ and $\mathrm{C}-6$, and $\mathrm{H}_{2}-4$ and C-6, as well as a weak correlation between $\mathrm{H}-2$ and $\mathrm{C}-8$, which showed connectivity along the fused lactone-furanone fragment. Thus, the planar structure of $\mathbf{1}$ was established as shown. Establishment of the relative configuration of $\mathbf{1}$ was conducted using NOESY correlations, which were observed from $\mathrm{H}_{3}-9$ to $\mathrm{H}-5$ to $\mathrm{H}-8$ to $\mathrm{H}-2$ to $\mathrm{OH}$, indicating that these protons were on the same face of the compound. An additional correlation from $\mathrm{H}-3$ to $\mathrm{H}-10$ indicated that these two protons were on the same face to each other but on the opposite face to the previous set establishing the relative configuration of 1 as $\mathrm{H}_{3}-9 / \mathrm{H}-5 / \mathrm{H}-8 / \mathrm{H}-2 / \mathrm{OH}$ as $\alpha$ orientation while $\mathrm{H}-3 / \mathrm{H}-7 / \mathrm{H}-10$ as $\beta$ orientation.

Table 1. Comparison of ${ }^{1} \mathrm{H}-\mathrm{NMR}$ data of $\mathbf{1}$ with $\mathbf{5}$ and $\mathbf{6}$ in $\mathrm{CDCl}_{3}$.

\begin{tabular}{cccc}
\hline Position & \multicolumn{3}{c}{$\boldsymbol{\delta}_{\mathbf{H}}(\mathbf{m}, \mathbf{J}$ in $\mathbf{H z})$} \\
\hline & $\mathbf{1}^{\mathbf{a}}$ & $\mathbf{5}^{\mathbf{b}}$ & $\mathbf{6}^{\mathbf{b}}$ \\
\hline 1 & - & - & - \\
2 & $3.45(\mathrm{dd}, 9.0,7.7)$ & $3.45(\mathrm{dd}, 9.0,7.3)$ & $3.87-3.85(\mathrm{~m})$ \\
3 & $3.34(\mathrm{ddd}, 11.0,9.0,5.0)$ & $3.30(\mathrm{dddd}, 11.0,9.0,5.0,2.4)$ & $3.74-3.71(\mathrm{~m})$ \\
4 & $2.64(\mathrm{ddd}, 13.4,5.0,2.0)$, & $2.62(\mathrm{ddd}, 13.3,5.0,2.0)$, & $2.62-2.57(\mathrm{~m})$, \\
5 & $1.73(\mathrm{ddd}, 13.4,11.0,6.1)$ & $1.71(\mathrm{ddd}, 13.3,11.0,6.1)$ & $2.03(\mathrm{ddd}, 15.3,8.0,3.6)$ \\
6 & $2.90(\mathrm{ddd}, 6.1,4.1,2.0)$ & $2.87(\mathrm{ddd}, 6.1,3.1,2.0)$ & $2.62-2.57(\mathrm{~m})$ \\
7 & - & - & - \\
8 & $4.58(\mathrm{q}, 7.0)$ & $4.50(\mathrm{dq}, 3.1,6.7)$ & $4.52(\mathrm{dq}, 3.6,6.7)$ \\
9 & $4.04(\mathrm{~d}, 4.1)$ & $4.12(\mathrm{dd}, 3.1,3.1)$ & $4.21(\mathrm{dd}, 3.6,3.6)$ \\
10 & $1.33(\mathrm{~d}, 7.0)$ & $1.44(\mathrm{~d}, 6.7)$ & $1.52(\mathrm{~d}, 6.7)$ \\
11 & $5.42(\mathrm{ddq}, 15.5,7.7,1.6)$ & $5.44(\mathrm{ddq}, 15.3,7.3,1.2)$ & $5.52(\mathrm{ddq}, 15.3,4.9,1.8)$ \\
12 & $5.89(\mathrm{dq}, 15.5,6.6)$ & $5.85(\mathrm{dq}, 15.3,6.1)$ & $5.84(\mathrm{dq}, 15.3,6.7)$ \\
$\mathrm{OH}$ & $1.77(\mathrm{dd}, 6.6,1.6)$ & $1.76(\mathrm{br} \mathrm{d}, 6.1)$ & $1.75(\mathrm{dd}, 6.7,1.8)$ \\
\hline
\end{tabular}

${ }^{\text {a }}$ Data recorded at $500 \mathrm{MHz}$ in $\mathrm{CDCl}_{3} .{ }^{\mathrm{b}}$ Data from Gao et al. [1] recorded at $400 \mathrm{MHz}$ in $\mathrm{CDCl}_{3}$.

Table 2. Comparison of ${ }^{13} \mathrm{C}-\mathrm{NMR}$ data of $\mathbf{1}$ with $\mathbf{5}$ and $\mathbf{6}$ in $\mathrm{CDCl}_{3}$.

\begin{tabular}{cccc}
\hline Position & $\mathbf{1}^{\mathbf{a}}$ & $\mathbf{5}^{\mathbf{b}}$ & $\mathbf{6}^{\mathbf{b}}$ \\
\hline 1 & - & - & - \\
2 & 81.5 & 78.2 & 76.9 \\
3 & 66.6 & 66.5 & 65.2 \\
4 & 28.3 & 28.4 & 27.8 \\
5 & 39.0 & 42.9 & 38.2 \\
6 & 176.0 & 176.3 & 177.0 \\
7 & 80.5 & 80.9 & 78.5 \\
8 & 77.7 & 74.6 & 75.1 \\
9 & 17.6 & 13.5 & 13.4 \\
10 & 127.8 & 127.8 & 127.7 \\
11 & 133.0 & 131.4 & 128.7 \\
12 & 18.2 & 18.0 & 18.0 \\
\hline
\end{tabular}

Since it was noted that $\mathbf{1}$ and $5-7$ were isomeric, the spectroscopic data of these compounds were compared. Both the ${ }^{1} \mathrm{H}$ and ${ }^{13} \mathrm{C}-\mathrm{NMR}$ data of $\mathbf{1}$ (Tables 1 and 2) were very similar to those of synthetic intermediate 5 with the exception of $\mathrm{H}_{3}-9$. For $1, \mathrm{H}_{3}-9$ was observed at $\delta_{\mathrm{H}} 1.33$ with a carbon signal of $\delta_{\mathrm{C}} 17.6$, while, for 5 , the proton signal was observed at $\delta_{\mathrm{H}} 1.44$ and the corresponding carbon at $\delta_{\mathrm{C}}$ 13.5. This locus of difference suggested that 1 is the C-7 epimer of 5 . The NMR data of compound 6 
showed significant changes in comparison to 1 around both the lactone and furanone rings as expected since 6 is epimeric with 1 at C-3 and C-7.
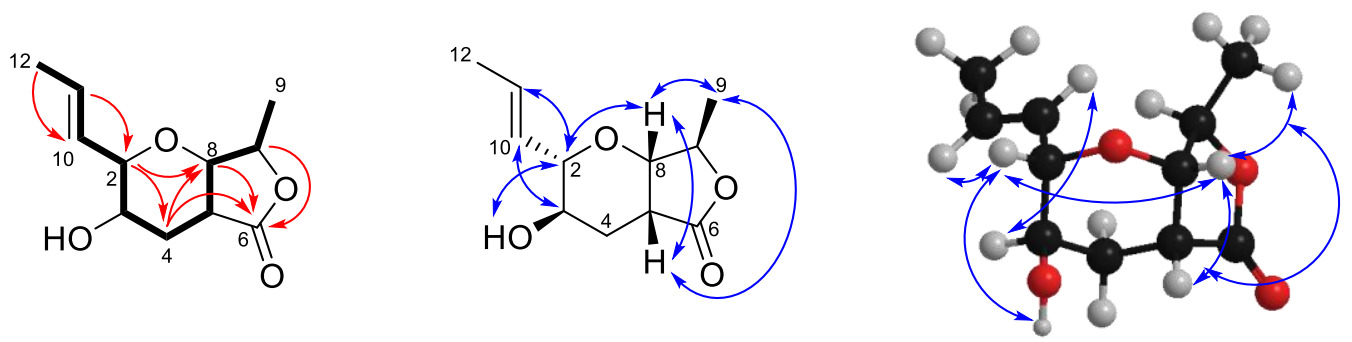

Figure 3. Selected COSY (bold), HMBC (red arrows) and NOESY (blue arrows) correlations for 1.

Comparison of the ${ }^{1} \mathrm{H}$ and ${ }^{13} \mathrm{C}-\mathrm{NMR}$ data of $\mathbf{1}$ in $\mathrm{CD}_{3} \mathrm{OD}$ (Table 3, Figures S2 and S3) with theissenolactone A (7) showed that the data were identical [2]. This was surprising as the reported relative configuration of 7 indicated that 1 should be the cis isomer of 7 at the $H-5 / \mathrm{H}-8$ bridge. Examination of the coupling constants across the H-5/H-8 bridge showed that for $7 \mathrm{H}-8$ was observed as a singlet [2]. This was inconsistent with previously reported data for trans bridge head protons, for a related natural product trans-dihydrowaol A (8), which had a coupling constant of $J=12 \mathrm{~Hz}$ [3]. In the current study, we observed a small coupling constant of $J=4.3 \mathrm{~Hz}$ for the $\mathrm{H}-5 / \mathrm{H}-8$ bridge which was consistent with the coupling constants previously published for cis isomers $\mathbf{5}(J=3.1 \mathrm{~Hz})$ and $\mathbf{6}$ $(J=3.6 \mathrm{~Hz})$ [1]. The optical rotation of $7,[\alpha]_{\mathrm{D}}{ }^{28}=+47.7(c=0.45, \mathrm{MeOH})$ [2], was higher in magnitude in comparison to $1,[\alpha]_{\mathrm{D}}{ }^{22}=+23.7(c=0.16, \mathrm{MeOH})$, but was of the same sign. Taken together, these results indicate 1 and $\mathbf{7}$ are the same compound and thus the correct structure of theissenolactone $\mathrm{A}$ is $\mathbf{1}$.

Table 3. Comparison of ${ }^{1} \mathrm{H}$ and ${ }^{13} \mathrm{C}-\mathrm{NMR}$ data $\left(\mathrm{CD}_{3} \mathrm{OD}\right)$ of 1 with theissenolactone $\mathrm{A}$.

\begin{tabular}{|c|c|c|c|c|}
\hline \multirow{2}{*}{ Position } & \multicolumn{2}{|l|}{1} & \multicolumn{2}{|c|}{ Theissenolactone A (7) } \\
\hline & $\delta_{H}(\mathrm{~m}, J \text { in } \mathrm{Hz})^{a}$ & $\delta_{C}{ }^{b}$ & $\delta_{\mathrm{H}}(\mathrm{m}, J \text { in } \mathrm{Hz})^{c}$ & $\delta_{C}^{d}$ \\
\hline 1 & - & - & - & - \\
\hline 2 & $3.46(\mathrm{dd}, 9.0,7.6)$ & 81.9 & $3.44(\mathrm{dd}, 7.9,7.7)$ & 81.9 \\
\hline 3 & $3.15(\mathrm{ddd}, 11.0,9.0,5.0)$ & 68.0 & $3.11-3.15(\mathrm{~m})$ & 68.0 \\
\hline 4 & $\begin{array}{l}2.45(\mathrm{ddd}, 13.4,5.0,2.0) \\
1.75(\mathrm{ddd}, 13.4,11.0,6.5)\end{array}$ & 30.2 & $\begin{array}{c}2.43(\mathrm{dd}, 11.2,5.0), \\
1.74(\mathrm{~d}, 11.2)\end{array}$ & 30.1 \\
\hline 5 & $3.13(\mathrm{ddd}, 6.5,4.3,2.0)$ & 40.4 & $3.08-3.12(\mathrm{~m})$ & 40.4 \\
\hline 6 & - & 178.8 & - & 178.9 \\
\hline 7 & $4.53(q, 6.8)$ & 82.2 & $4.50(q, 6.8)$ & 82.3 \\
\hline 8 & $4.10(\mathrm{~d}, 4.3)$ & 78.9 & $4.07(\mathrm{~s})$ & 78.9 \\
\hline 9 & $1.34(\mathrm{~d}, 6.8)$ & 17.4 & $1.31(\mathrm{~d}, 6.8)$ & 17.4 \\
\hline 10 & $5.48(\mathrm{ddd}, 15.3,7.6,1.6)$ & 129.8 & $5.45(\mathrm{dd}, 15.8,7.9)$ & 129.8 \\
\hline 11 & $5.80(\mathrm{dq}, 15.3,6.5)$ & 130.7 & $5.76(\mathrm{dq}, 15.8,6.7)$ & 130.7 \\
\hline 12 & $1.73(\mathrm{br} \mathrm{d}, 6.5)$ & 18.1 & $1.70(\mathrm{~d}, 6.7)$ & 18.1 \\
\hline
\end{tabular}

a Data recorded at $500 \mathrm{MHz}$ in $\mathrm{CD}_{3} \mathrm{OD} .{ }^{\mathrm{b}}$ Data recorded at $125 \mathrm{MHz}$ in $\mathrm{CD}_{3} \mathrm{OD} .{ }^{\mathrm{c}}$ Data from Liang et al. [2] recorded at $500 \mathrm{MHz}$ in $\mathrm{CD}_{3} \mathrm{OD}$. ${ }^{\mathrm{d}}$ Data from Liang et al. [2] recorded at $125 \mathrm{MHz}$ in $\mathrm{CD}_{3} \mathrm{OD}$.

To establish the absolute configuration of $\mathbf{1}$, the chiral derivatizing agent $\alpha$-methoxyphenylacetic acid (MPA) was used to prepare diastereomeric esters at C-3. Treatment of 1 with (S)-MPA and $(R)$-MPA, respectively, in the presence of EDC.HCl and DMAP afforded derivatives $\mathbf{1 a}$ and $\mathbf{1 b}$. Comparison of the ${ }^{1} \mathrm{H}-\mathrm{NMR}$ spectra of the two compounds (Figure 4), especially those of $\mathrm{H}_{2}-4, \mathrm{H}-3, \mathrm{H}-2, \mathrm{H}-10$ and $\mathrm{H}-11$, identified a change in $\delta(R)-\delta(S)$ as positive, establishing $S$ configuration at H-3 [4]. Thus, the absolute configuration of $\mathbf{1}$ was assigned as $2 R, 3 S, 5 S, 7 S, 8 R$. Further confirmation of the absolute configuration of $\mathbf{1}$ was derived from computational chemistry. Boltzmann-population weighted (Table S2) specific rotation calculated at the CAM-B3LYP/aug-cc-PVTZ level of theory agreed in sign 
and magnitude (+45.8) with the reported values for $\mathbf{1}(+47.7$ [2], +23.7 (current study)). The electronic circular dichroism spectrum of 1 was acquired as exhibited a single absorbance at $\lambda_{\max } 217 \mathrm{~nm}(\Delta \varepsilon 1.94)$ (Figure 5). Using the same Boltzmann-population weighting, the TDDFT calculated ECD spectrum, calculated at the CAM-B3LYP/def2SVP level of theory, was in close agreement $\left(\Delta \varepsilon 2.25, \lambda_{\max } 210 \mathrm{~nm}\right)$ with the observed spectrum.

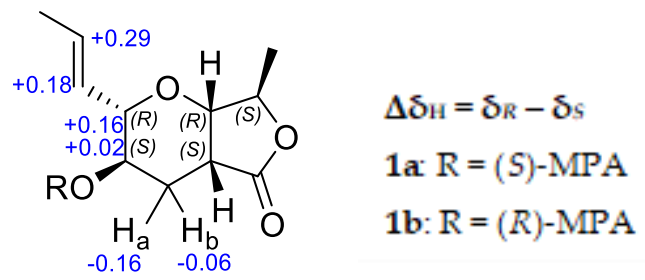

Figure 4. $\Delta \delta_{\mathrm{H}}$ values obtained for (S)-MPA and (R)-MPA ester derivatives (1a and $\mathbf{1 b}$, respectively) of $\mathbf{1}$ in $\mathrm{CDCl}_{3}$.

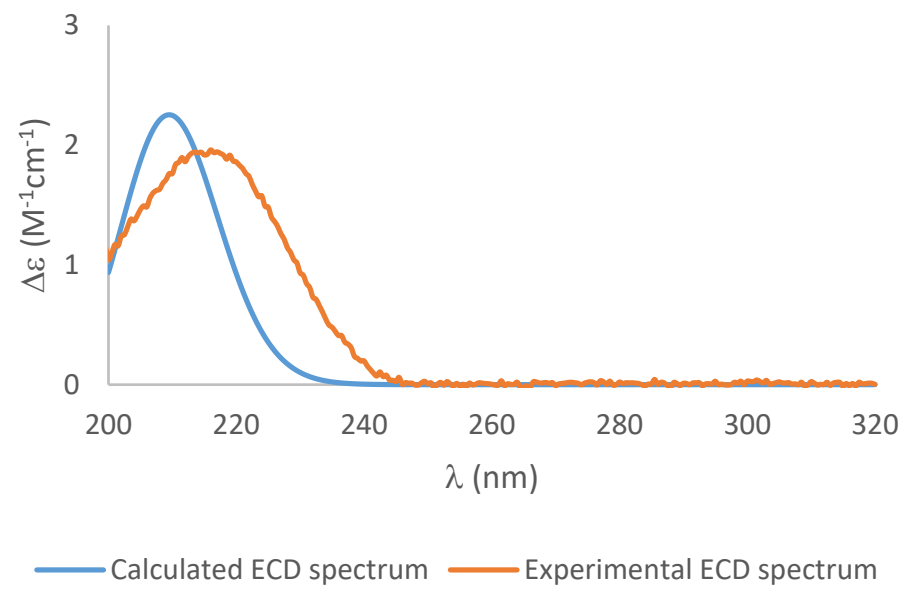

Figure 5. The experimental ECD spectrum (orange), and the calculated ECD spectrum of $\mathbf{1}$ (blue) (blue shift $=-6)$.

The structures of the known compounds were identified as $(3 S, 4 S)-4,8$-dihydroxy-3methylisochroman-1-one (2) [5], (3S,4R)-4,8-dihydroxy-3-methylisochroman-1-one (3) [5] and 7-hydroxy-3-(1-hydroxyethyl)isobenzofuran-1(3H)-one (4) [6].

Pure compounds 1-3 were tested for antimicrobial activity against a panel of bacteria including Methicillin-resistant Staphylococcus aureus, Pseudomonas aeruginosa, Escherichia coli, Klebsiella pneumoniae and Acinetobacter baumanii as well as two fungal strains, Candida albicans and Cryptococcus neoformans (Table 4). None of the compounds exhibited activity at a dose of $32 \mu \mathrm{g} / \mathrm{mL}$.

Table 4. Antimicrobial activity of compounds 1-3.

\begin{tabular}{|c|c|c|c|c|c|c|c|}
\hline \multirow{2}{*}{ Compound } & \multicolumn{7}{|c|}{ MIC ( $\mu \mathrm{g} / \mathrm{mL})$} \\
\hline & S. $a^{a}$ & P. $a^{b}$ & E. $c^{c}$ & $K \cdot p^{d}$ & A. $b^{e}$ & C. $a^{f}$ & C. $n^{g}$ \\
\hline 1 & $>32^{h}$ & $>32^{h}$ & $>32^{h}$ & $>32^{h}$ & $>32^{h}$ & $>32^{h}$ & $>32^{h}$ \\
\hline 2 & $>32^{h}$ & $>32^{h}$ & $>32^{h}$ & $>32^{h}$ & $>32^{h}$ & $>32^{h}$ & $>32^{h}$ \\
\hline 3 & $>32^{h}$ & $>32^{h}$ & $>32^{h}$ & $>32^{h}$ & $>32^{h}$ & $>32^{h}$ & $>32^{h}$ \\
\hline
\end{tabular}

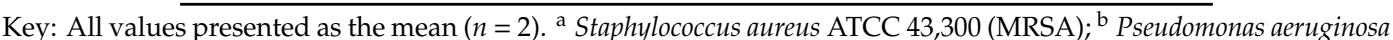
ATCC 27853; ' Escherichia coli ATCC 25922; d Klebsiella pneumoniae ATCC 700,603; ' Acinetobacter baumanii ATCC 19,$606 ;{ }^{\mathrm{f}}$ Candida albicans ATCC 90028; $\mathrm{g}$ Cryptococcus neoformans ATCC 208821; ${ }^{\mathrm{h}}$ not active at a single dose test of $32 \mu \mathrm{g} / \mathrm{mL}$. 


\section{Materials and Methods}

\subsection{General Experimental Procedures}

Infrared spectra were recorded on a Perkin-Elmer spectrometer 100 Fourier Transform infrared spectrometer equipped with a universal ATR accessory. HRMS data were acquired on a Bruker micrOTOF QII spectrometer. NMR spectra were recorded on a Bruker Avance DRX-400 spectrometer or an Avance III-HD 500 spectrometer operating at 400 or $500 \mathrm{MHz}$ for ${ }^{1} \mathrm{H}$ nuclei and $100 \mathrm{or} 125 \mathrm{MHz}$ for ${ }^{13} \mathrm{C}$ nuclei. Proto-deutero solvent signals were used as internal references (DMSO- $d_{6}: \delta_{\mathrm{H}} 2.50$, $\delta_{\mathrm{C}} 39.52, \mathrm{CD}_{3} \mathrm{OD}: \delta_{\mathrm{H}} 3.31, \delta_{\mathrm{C}} 49.00$ and $\left.\mathrm{CDCl}_{3}: \delta_{\mathrm{H}} 7.26, \delta_{\mathrm{C}} 77.16\right)$. For ${ }^{1} \mathrm{H} \mathrm{NMR}$, the data are quoted as position $(\delta)$, relative integral, multiplicity $(\mathrm{s}=$ singlet, $\mathrm{d}=$ doublet, $\mathrm{t}=$ triplet, $\mathrm{q}=$ quartet, $\mathrm{m}=$ multiplet, $\mathrm{br}=$ broad $)$, coupling constant $(\mathrm{J}, \mathrm{Hz})$ and assignment to the atom. The ${ }^{13} \mathrm{C}-\mathrm{NMR}$ data are quoted as position $(\delta)$ and assignment to the atom. Flash column chromatography was carried out using either Merck Diol bonded silica $(40-63 \mu \mathrm{m})$, Davisil silica gel $(40-63 \mu \mathrm{m})$ or Merck $C_{8}$ reversed-phase (40-63 $\mu \mathrm{m})$ solid support. Thin layer chromatography was conducted on Merck DC-plastikfolien Kieselgel 60 F254 plates. All solvents used were of analytical grade or better and/or purified according to standard procedures.

\subsection{Fungal Material}

All fungal isolates were provided by Manaaki Whenua-Landcare Research responsible for the curation of the International Collection of Microorganisms from Plants (ICMP). The ascomycete fungus Microcera larvarum, culture ICMP 5444, was isolated from a dead scale insect in December 1974 in Tauranga, Aotearoa New Zealand [7]. Fungal isolates were stored individually in cryotubes at $-80^{\circ} \mathrm{C}$. Freezer stocks were made by growing the fungus on $1.5 \%$ potato dextrose agar (PDA) plate and excising small cubes of agar (5-6 mm in length) from the fungus' growing edge. These cubes were placed within a cryovial containing $1 \mathrm{~mL}$ of $10 \%$ glycerol. The cryovials were rested for $1 \mathrm{~h}$ after which the remaining liquid glycerol was removed, and the tubes stored at $-80{ }^{\circ} \mathrm{C}$.

\subsection{Fermentation, Extraction and Isolation}

Forty PDA plates were inoculated with ICMP 5444 and incubated at room temperature for 4 weeks. Fully grown fungal plates were freeze-dried (13.40 g, dry weight) and extracted with $\mathrm{MeOH}(2 \times 500 \mathrm{~mL})$ for $4 \mathrm{~h}$ followed $\mathrm{CH}_{2} \mathrm{Cl}_{2}(2 \times 500 \mathrm{~mL})$ overnight. Combined organic extracts were concentrated under reduced pressure to afford a yellow oil (0.51 g). The crude product was subjected to $\mathrm{C}_{8}$ reversed-phase column chromatography eluting with a gradient of $\mathrm{H}_{2} \mathrm{O} / \mathrm{MeOH}$ to afford five fractions (F1-F5). F2 was subjected to purification by Diol-bonded silica gel column chromatography, eluting with gradient $n$-hexane/EtOAc to afford 7-hydroxy-3-(1hydroxyethyl)isobenzofuran-1(3H)-one (4) (1.50 mg). Purification of F3 by Diol-bonded silica gel column chromatography, eluting with gradient $n$-hexane/EtOAc, afforded four fractions (A1-A4). Fraction A2 afforded $(3 S, 4 S)$ 4-hydroxymellein (2) $(9.0 \mathrm{mg})$ while fraction A3 afforded (2R,3S,4aS,7S,7aR)-3-hydroxy-7-methyl-2-((E)-prop-1-en-1-yl)hexahydro-5H-furo[3,4-b]pyran-5-one (1) (3.09 $\mathrm{mg}$ ) after further purification by silica gel column chromatography, eluting with gradient $n$-hexane/EtOAc. Purification of F4 by Diol-bonded silica gel column chromatography, eluting with gradient $n$-hexane/EtOAc, afforded (3S,4R) 4-hydroxymellein (3) (4.0 mg).

3.3.1. (2R,3S,4aS,7S,7aR)-3-Hydroxy-7-methyl-2-((E)-prop-1-en-1-yl)hexahydro-5H-furo[3,4b]pyran-5-one (1)

White solid; $[\alpha]_{\mathrm{D}}{ }^{22}=+23.7(c=0.16, \mathrm{MeOH}) ; \mathrm{UV}(\mathrm{MeOH}) \lambda_{\max }[\log \varepsilon] 318.5$ (2.30), 224.0 (2.93), 204.5 (3.38); ECD (MeOH) $\lambda_{\max }(\Delta \varepsilon) 216$ (+1.94); m.p. 129-131 ${ }^{\circ} \mathrm{C} ; \mathrm{R}_{\mathrm{f}} 0.70$ (EtOAc); IR (ATR) $\mathrm{v}_{\max } 2959$, 2949, 2917, 1649, 1457, 1377, $666 \mathrm{~cm}^{-1}$; Refer to Tables 1 and 2 for ${ }^{1} \mathrm{H}$ and ${ }^{13} \mathrm{C}-\mathrm{NMR}$ data; (+)-HRESIMS $m / z 235.0940[\mathrm{M}+\mathrm{Na}]^{+}$(calcd for $\left.\mathrm{C}_{11} \mathrm{H}_{16} \mathrm{NaO}_{4}, 235.0941\right)$. 


\subsection{2. (3S,4R)-4-Hydroxymellein (2)}

White solid; $[\alpha]_{\mathrm{D}}{ }^{19}=+38.2(c=0.10, \mathrm{MeOH})\left[\operatorname{lit}[\alpha]_{\mathrm{D}}{ }^{20}=+32(c=0.1, \mathrm{MeOH})[5]\right] ;$ m.p. $124-126^{\circ} \mathrm{C}$; ${ }^{1} \mathrm{H}-\mathrm{NMR}\left(\mathrm{CD}_{3} \mathrm{OD}, 400 \mathrm{MHz}\right) 7.55(1 \mathrm{H}, \mathrm{dd}, J=8.4,7.4 \mathrm{~Hz}, \mathrm{H}-6), 6.97(1 \mathrm{H}, \mathrm{d}, J=8.4 \mathrm{~Hz}, \mathrm{H}-5), 6.97$ $(1 \mathrm{H}, \mathrm{dd}, J=7.4 \mathrm{~Hz}, \mathrm{H}-7), 4.72(1 \mathrm{H}, \mathrm{qd}, J=6.6,2.0 \mathrm{~Hz}, \mathrm{H}-3), 4.56(1 \mathrm{H}, \mathrm{d}, J=2.0 \mathrm{~Hz}, \mathrm{H}-4), 1.52(3 \mathrm{H}, \mathrm{d}$, $\left.J=6.6 \mathrm{~Hz}, \mathrm{H}_{3}-9\right)$ [data agreed with literature [5]]; ${ }^{1} \mathrm{H}-\mathrm{NMR}\left(\mathrm{DMSO}-d_{6}, 400 \mathrm{MHz}\right) \delta 10.97(1 \mathrm{H}, \mathrm{br} \mathrm{s}$, 8-OH), 7.60 (1H, dd, J = 8.5, 8.2 Hz, H-6), $6.99(1 \mathrm{H}, \mathrm{dd}, J=8.5,1.0 \mathrm{~Hz}, \mathrm{H}-5), 6.97(1 \mathrm{H}, \mathrm{dd}, J=8.2,1.0 \mathrm{~Hz}$, $\mathrm{H}-7), 5.72(1 \mathrm{H}, \mathrm{d}, J=6.3 \mathrm{~Hz}, 4-\mathrm{OH}), 4.77(1 \mathrm{H}, \mathrm{dq}, J=6.6,2.0 \mathrm{~Hz}, \mathrm{H}-3), 4.52(1 \mathrm{H}, \mathrm{dd}, J=6.3,2.0 \mathrm{~Hz}, \mathrm{H}-4)$, $1.41\left(3 \mathrm{H}, \mathrm{d}, J=6.6 \mathrm{~Hz}, \mathrm{H}_{3}-9\right) ;{ }^{13} \mathrm{C}-\mathrm{NMR}$ (DMSO-d $\left.6,100 \mathrm{MHz}\right) \delta 169.0$ (C-1), 160.5 (C-8), 142.4 (C-4a), 136.4 (C-6), 118.7 (C-5), 116.7 (C-7), 107.4 (C-8a), 78.3 (C-3), 65.2 (C-4), 15.8 (C-9); (+)-HRESIMS m/z 217.0476 [M + Na] ${ }^{+}$(calcd for $\mathrm{C}_{10} \mathrm{H}_{10} \mathrm{NaO}_{4}, 217.0470$ ).

\subsection{3. (3S,4S)-4-Hydroxymellein (3)}

White solid; $[\alpha]_{\mathrm{D}}{ }^{19}=+21.2(c=0.07, \mathrm{MeOH})\left[\mathrm{lit}[\alpha]_{\mathrm{D}}=+37.4(c=0.33, \mathrm{MeOH})[8]\right] ;{ }^{1} \mathrm{H}-\mathrm{NMR}$ $\left(\mathrm{CD}_{3} \mathrm{OD}, 400 \mathrm{MHz}\right) \delta 7.57(1 \mathrm{H}, \mathrm{dd}, J=8.5,7.6 \mathrm{~Hz}, \mathrm{H}-6), 7.08(1 \mathrm{H}, \mathrm{d}, J=7.6 \mathrm{~Hz}, \mathrm{H}-5), 6.93(1 \mathrm{H}$, $\mathrm{d}, J=8.5 \mathrm{~Hz}, \mathrm{H}-7), 4.57-4.53(2 \mathrm{H}, \mathrm{m}, \mathrm{H}-3, \mathrm{H}-4), 1.47\left(3 \mathrm{H}, \mathrm{d}, J=6.1 \mathrm{~Hz}, \mathrm{H}_{3}-9\right)$ [data agreed with literature [5]]; ${ }^{1} \mathrm{H}-\mathrm{NMR}$ (DMSO- $\left.d_{6}, 400 \mathrm{MHz}\right) \delta 10.88(1 \mathrm{H}, \mathrm{br} \mathrm{s}, 8-\mathrm{OH}), 7.60(1 \mathrm{H}, \mathrm{dd}, J=8.4,8.4 \mathrm{~Hz}$, H-6), $7.05(1 \mathrm{H}, \mathrm{d}, J=8.4 \mathrm{~Hz}, \mathrm{H}-5), 6.94(1 \mathrm{H}, \mathrm{d}, J=8.4 \mathrm{~Hz}, \mathrm{H}-7), 6.10(1 \mathrm{H}, \mathrm{br} \mathrm{s}, 4-\mathrm{OH}), 4.56-4.53(2 \mathrm{H}, \mathrm{m}$, H-3, H-4), 1.39 (3H, d, $\left.J=6.0 \mathrm{~Hz}, \mathrm{H}_{3}-9\right) ;{ }^{13} \mathrm{C}-\mathrm{NMR}$ (DMSO-d 6 , $\left.100 \mathrm{MHz}\right) \delta 169.0$ (C-1), 160.5 (C-8), 142.4 (C-4a), 136.4 (C-6), 118.7 (C-5), 116.7 (C-7), 107.4 (C-8a), 78.3 (C-3), 65.2 (C-4), 15.8 (C-9); (+)-HRESIMS $\mathrm{m} / z 217.0475[\mathrm{M}+\mathrm{Na}]^{+}$(calcd for $\left.\mathrm{C}_{10} \mathrm{H}_{10} \mathrm{NaO}_{4}, 217.0470\right)$.

\subsubsection{7-Hydroxy-3-(1-hydroxyethyl)isobenzofuran-1(3H)-one (4)}

White solid; $[\alpha]_{\mathrm{D}}{ }^{21}=-14.7\left(c=0.14, \mathrm{CHCl}_{3}\right)\left[\right.$ lit $[\alpha]_{\mathrm{D}}{ }^{20}=-50.0\left(c=0.08, \mathrm{CHCl}_{3}\right)$ [6]]; m.p. 101-103 ${ }^{\circ} \mathrm{C}$ [lit 102-103 $\left.{ }^{\circ} \mathrm{C}[6,9]\right] ;{ }^{1} \mathrm{H}-N M R$ (DMSO- $\left.d_{6}, 400 \mathrm{MHz}\right) \delta 10.63(1 \mathrm{H}$, br s, 7-OH), $7.51(1 \mathrm{H}, \mathrm{dd}$, $J=8.0,7.6 \mathrm{~Hz}, \mathrm{H}-5), 7.03(1 \mathrm{H}, \mathrm{d}, J=7.6 \mathrm{~Hz}, \mathrm{H}-4), 6.90(1 \mathrm{H}, \mathrm{d}, J=8.0 \mathrm{~Hz}, \mathrm{H}-6), 5.28(1 \mathrm{H}, \mathrm{d}, J=4.5 \mathrm{~Hz}$, H-3), $5.22(1 \mathrm{H}, \mathrm{d}, J=5.4 \mathrm{~Hz}, 8-\mathrm{OH}), 3.95-3.91\left(2 \mathrm{H}, \mathrm{m}, \mathrm{H}_{2}-8\right), 1.05\left(3 \mathrm{H}, \mathrm{d}, J=6.5 \mathrm{~Hz}, \mathrm{H}_{3}-9\right) ;{ }^{13} \mathrm{C}-\mathrm{NMR}$ (DMSO- $\left.d_{6}, 100 \mathrm{MHz}\right) \delta 168.2$ (C-1), 156.8 (C-7), 149.7 (C-3a), 135.7 (C-5), 115.8 (C-6), 113.4 (C-4), 111.7 (C-7a), 83.0 (C-3), 67.5 (C-8), 18.0 (C-9); (+)-HRESIMS m/z $217.0472[\mathrm{M}+\mathrm{Na}]^{+}$(calcd for $\mathrm{C}_{10} \mathrm{H}_{10} \mathrm{NaO}_{4}$, 217.0470).

\subsubsection{Preparation of (S)-MPA derivative of 1}

To $1(0.40 \mathrm{mg}, 1.9 \mu \mathrm{mol})$ in anhydrous $\mathrm{CH}_{2} \mathrm{Cl}_{2}(0.5 \mathrm{~mL})$ under nitrogen atmosphere was added (S)-(+)- $\alpha$-methoxyphenylacetic acid $(0.78 \mathrm{mg}, 4.7 \mu \mathrm{mol})$, EDC.HCl $(0.90 \mathrm{mg}, 4.7 \mu \mathrm{mol})$ and DMAP $(0.57 \mathrm{mg}, 4.7 \mu \mathrm{mol})$ successively and the reaction was stirred overnight. Water was added and the crude product was extracted with diethyl ether $(2 \times 5 \mathrm{~mL})$. The combined organic extracts were washed with $10 \% \mathrm{HCl}(5 \mathrm{~mL})$, water $(5 \mathrm{~mL})$, sat aq. $\mathrm{NaHCO}_{3}(5 \mathrm{~mL})$ and water $(5 \mathrm{~mL})$ successively and dried over anhydrous $\mathrm{MgSO}_{4}$. Solvent was then removed under pressure to afford (S)-MPA derivative (1a) of 1 as a colorless oil $\left(0.40 \mathrm{mg}, 58.8 \%\right.$ yield). ${ }^{1} \mathrm{H}-\mathrm{NMR}\left(\mathrm{CDCl}_{3}, 400 \mathrm{MHz}\right) \delta 7.39-7.32(5 \mathrm{H}, \mathrm{m}, \mathrm{ArH}-\mathrm{MPA})$, $5.37(1 \mathrm{H}, \mathrm{dq}, J=15.5,6.6 \mathrm{~Hz}, \mathrm{H}-11), 5.11(1 \mathrm{H}, \mathrm{ddq}, J=15.5,7.7,1.6 \mathrm{~Hz}, \mathrm{H}-10), 4.72(1 \mathrm{H}, \mathrm{s}, \mathrm{C} \alpha \mathrm{H}-\mathrm{MPA})$, $4.69(1 \mathrm{H}, \mathrm{ddd}, J=11.0,9.0,5.0 \mathrm{~Hz}, \mathrm{H}-3), 4.55(1 \mathrm{H}, \mathrm{q}, J=7.0 \mathrm{~Hz}, \mathrm{H}-7), 3.92(1 \mathrm{H}, \mathrm{d}, J=4.1 \mathrm{~Hz}, \mathrm{H}-8)$, $3.51(1 \mathrm{H}, \mathrm{dd}, J=9.0,7.7 \mathrm{~Hz}, \mathrm{H}-2), 3.40$ (3H, s, OMe-MPA), $2.85(1 \mathrm{H}, \mathrm{ddd}, J=6.1,4.1,2.0 \mathrm{~Hz}, \mathrm{H}-5)$, $2.54\left(1 \mathrm{H}, \mathrm{ddd}, J=13.4,5.0,2.0 \mathrm{~Hz}, \mathrm{H}_{2}-4_{\mathrm{A}}\right), 1.90\left(1 \mathrm{H}, \mathrm{ddd}, J=13.4,11.0,6.1 \mathrm{~Hz}, \mathrm{H}_{2}-4_{\mathrm{B}}\right), 1.40(3 \mathrm{H}, \mathrm{dd}$, $\left.J=6.6,1.6 \mathrm{~Hz}, \mathrm{H}_{3}-12\right), 1.29\left(3 \mathrm{H}, \mathrm{d}, J=7.0 \mathrm{~Hz}, \mathrm{H}_{3}-9\right) ;(+)$-HRESIMS $\mathrm{m} / z 383.1503\left[\mathrm{M}+\mathrm{Na}^{+}\right.$(calcd for $\mathrm{C}_{20} \mathrm{H}_{24} \mathrm{NaO}_{6}, 383.1470$ ).

\subsubsection{Preparation of (R)-MPA derivative of $\mathbf{1}$}

To $1(0.50 \mathrm{mg}, 2.4 \mu \mathrm{mol})$ in anhydrous $\mathrm{CH}_{2} \mathrm{Cl}_{2}(0.5 \mathrm{~mL})$ under nitrogen atmosphere was added $(R)-(-)-\alpha$-methoxyphenylacetic acid $(0.98 \mathrm{mg}, 5.9 \mu \mathrm{mol})$, EDC.HCl $(1.13 \mathrm{mg}, 5.9 \mu \mathrm{mol})$ and DMAP $(0.72 \mathrm{mg}, 5.9 \mu \mathrm{mol})$ successively and the reaction was stirred overnight. Water was added and the crude 
product was extracted with diethyl ether $(2 \times 5 \mathrm{~mL})$. The combined organic extracts were washed with $10 \% \mathrm{HCl}(5 \mathrm{~mL})$, water $(5 \mathrm{~mL})$, sat aq. $\mathrm{NaHCO}_{3}(5 \mathrm{~mL})$ and water $(5 \mathrm{~mL})$ successively and dried over anhydrous $\mathrm{MgSO}_{4}$. Solvent was then removed under pressure to afford $(R)$-MPA derivative (1b) of $\mathbf{1}$ as a colorless oil $(0.47 \mathrm{mg}, 54.7 \%$ yield $) .{ }^{1} \mathrm{H}-\mathrm{NMR}\left(\mathrm{CDCl}_{3}, 400 \mathrm{MHz}\right) \delta 7.41-7.33(5 \mathrm{H}, \mathrm{m}, \mathrm{ArH}-\mathrm{MPA})$, $5.66(1 \mathrm{H}, \mathrm{dq}, J=15.5,6.6 \mathrm{~Hz}, \mathrm{H}-11), 5.29(1 \mathrm{H}, \mathrm{ddq}, J=15.5 .7 .7,1.6 \mathrm{~Hz}, \mathrm{H}-10), 4.71(1 \mathrm{H}, \mathrm{ddd}, J=11.0$, 9.0, $5.0 \mathrm{~Hz}, \mathrm{H}-3), 4.70(1 \mathrm{H}, \mathrm{s}, \mathrm{C} \alpha \mathrm{H}-\mathrm{MPA}), 4.57(1 \mathrm{H}, \mathrm{q}, J=7.0 \mathrm{~Hz}, \mathrm{H}-7), 3.98(1 \mathrm{H}, \mathrm{d}, J=4.1 \mathrm{~Hz}, \mathrm{H}-8)$, $3.67(1 \mathrm{H}, \mathrm{dd}, J=9.0,7.7 \mathrm{~Hz}, \mathrm{H}-2), 3.40$ (3H, s, OMe-MPA), 2.74 (1H, ddd, J = 6.1, 4.1, 2.0 Hz, H-5), $2.38\left(1 \mathrm{H}, \mathrm{ddd}, J=13.4,5.0,2.0 \mathrm{~Hz}, \mathrm{H}_{2}-4_{\mathrm{A}}\right), 1.84\left(1 \mathrm{H}, \mathrm{ddd}, J=13.4,11.0,6.1 \mathrm{~Hz}, \mathrm{H}_{2}-4_{\mathrm{B}}\right), 1.54(3 \mathrm{H}, \mathrm{dd}$, $\left.J=6.6,1.6 \mathrm{~Hz}, \mathrm{H}_{3}-12\right), 1.29\left(3 \mathrm{H}, \mathrm{d}, J=7.0 \mathrm{~Hz}, \mathrm{H}_{3}-9\right)$; (+)-HRESIMS m/z 383.1468 [M + Na] ${ }^{+}$(calcd for $^{-}$ $\left.\mathrm{C}_{20} \mathrm{H}_{24} \mathrm{NaO}_{6}, 383.1470\right)$.

\subsection{Computational Details}

Conformational analysis of $\mathbf{1}$ was performed using the MMFF94 molecular mechanics force field via the Spartan '08 program. Seven conformers were identified in a $15 \mathrm{~kJ} / \mathrm{mol}$ window, which, upon initial geometry optimization at the DFT B3LYP/6-31G(d) level of theory and removal of duplicates, afforded four stable conformers (1a-d) (Figure S1). Each of these conformers was then re-optimized at the B3LYP/6-311+G(2d,p) level using Grimme's empirical dispersion corrections [10] with Becke-Johnson damping (D3BJ) [11] with addition of the integral equation formalism variant of Polarizable Continuum Model (IEFPCM, MeOH) in Gaussian 09W [12]. Harmonic vibrational frequencies were calculated for each conformer at the same level of theory to confirm their stability. The calculated relative and free energies of the four conformers and their room temperature equilibrium populations are given in Table S1. Electronic transition and rotational strength were calculated using TDDFT at the CAM-B3LYP/def2SVP level with consideration of the methanol solvent effect using the IEFPCM [13]. Boltzmann-weighting of UV and ECD spectra were performed using SpecDis [13,14] with a half-bandwidth of $0.30 \mathrm{eV}$ and UV correction of $-6 \mathrm{~nm}$. Specific rotations were calculated for each of conformers $1 a-d$ at the sodium D line $(589.3 \mathrm{~nm})$ using the B3LYP-D3(BJ)/6-311+G(2d,p) optimised geometries, with IEFPCM (MeOH), at two levels of theory: B3LYP/6-311+G(2d,p) and CAM-B3LYP/aug-cc-PVTZ. The Boltzmann-population weighted specific rotation values, +49.5 and +45.8 , respectively (Table S2) were in close agreement with the value previously reported for $\mathbf{1}(+47.7)$ [2] and approximately twice the observed magnitude for $\mathbf{1}$ in the current study (+23.7).

\subsection{Antimicrobial Testing of Extracts}

Following extraction and fractionation, broth microdilution testing of the extracts was performed to ascertain the antimicrobial activity of each of the fractions against S. aureus ATCC 29,213 and E. coli ATCC 25,922. Antimicrobial activity was determined by calculating the minimum inhibitory concentration (MIC) and the minimum bactericidal concentration (MBC). Tests were performed in a clear, flat bottom 96-well plate (Thermo Fisher, NUN167008) and bacterial growth determined within each well by measuring absorbance at $600 \mathrm{~nm}$ using an Enspire plate reader (Perkin Elmer, MA, USA).

Extracts were obtained as dried samples which were dissolved in DMSO to make a $25 \mathrm{mg} / \mathrm{mL}$ solution and then further diluted into Mueller Hinton broth II (MHB) to achieve a maximum concentration of $2 \mathrm{mg} / \mathrm{mL}$. Each extract $(200 \mu \mathrm{L})$ was added to two adjacent wells along the top of the 96-well plate. MHB $(100 \mu \mathrm{L})$ was then added to the remaining wells and extract solution $(100 \mu \mathrm{L})$ serially diluted two-fold down the plate and discarded, leaving the last row as a growth control. Aliquots of bacteria at an optical density at $600 \mathrm{~nm}$ of 0.01 (approximately $1 \times 10^{6}$ colony forming units (CFU)/mL) were then added to all the wells. This gave a maximum concentration of $1 \mathrm{mg} / \mathrm{mL}$ and a minimum concentration of $16 \mu \mathrm{g} / \mathrm{mL}$. An additional plate contained a sterile control row and a negative control well containing DMSO. The maximum volume/volume concentration of DMSO in all extracts was $4 \%$, therefore the negative control was tested at an identical concentration.

Absorbance was measured at 0,2, 4 and $20 \mathrm{~h}$, to determine MIC, between which times the plates were incubated at $37^{\circ} \mathrm{C}$ with shaking at $100 \mathrm{rpm}$. Following the $20 \mathrm{~h}$ time point, $10 \mu \mathrm{L}$ of liquid from 
all wells showing inhibition of bacterial growth was pipetted onto a plate of MH agar. The agar plates were placed inside a biosafety cabinet until all liquid had evaporated and then incubated inverted at $37^{\circ} \mathrm{C}$ for $16-20 \mathrm{~h}$ and the $\mathrm{MBC}$ was measured [15].

\subsection{Antimicrobial Assays of Pure Compounds}

Antimicrobial evaluation against S. aureus ATCC 43,300 (MRSA), E. coli ATCC 25,922, P. aeruginosa ATCC 27,853, Klebsiella pneumoniae ATCC 700,603, Acinetobacter baumannii ATCC 19,606, Candida albicans ATCC 90,028 and Cryptococcus neoformans ATCC 208,821 was undertaken at the Community for Open Antimicrobial Drug Discovery at The University of Queensland (Queensland, Australia) according to their standard protocols [16]. For antimicrobial assays, the tested strains were cultured in either Luria broth (LB) (In Vitro Technologies, USB75852, Victoria, Australia), nutrient broth (NB) (Becton Dickson, 234,000, New South Wales, Australia), or MHB at $37^{\circ} \mathrm{C}$ overnight. A sample of culture was then diluted 40-fold in fresh MHB and incubated at $37^{\circ} \mathrm{C}$ for $1.5-2 \mathrm{~h}$. The compounds were serially diluted 2-fold across the wells of 96-well plates (Corning 3641, nonbinding surface), with compound concentrations ranging from 0.015 to $64 \mu \mathrm{g} / \mathrm{mL}$, plated in duplicate. The resultant mid log phase cultures were diluted to the final concentration of $1 \times 10^{6} \mathrm{CFU} / \mathrm{mL}$; then, $50 \mu \mathrm{L}$ were added to each well of the compound containing plates giving a final compound concentration range of $0.008-32 \mu \mathrm{g} / \mathrm{mL}$ and a cell density of $5 \times 10^{5} \mathrm{CFU} / \mathrm{mL}$. All plates were then covered and incubated at $37^{\circ} \mathrm{C}$ for $18 \mathrm{~h}$. Resazurin was added at $0.001 \%$ final concentration to each well and incubated for $2 \mathrm{~h}$ before MICs were read by eye.

For the antifungal assay, fungi strains were cultured for 3 days on YPD agar at $30{ }^{\circ} \mathrm{C}$. A yeast suspension of $1 \times 10^{6}$ to $5 \times 10^{6} \mathrm{CFU} / \mathrm{mL}$ was prepared from five colonies. These stock suspensions were diluted with yeast nitrogen base (YNB) (Becton Dickinson, 233520, New South Wales, Australia) broth to a final concentration of $2.5 \times 10^{3} \mathrm{CFU} / \mathrm{mL}$. The compounds were serially diluted 2-fold across the wells of 96-well plates (Corning 3641, nonbinding surface), with compound concentrations ranging from 0.015 to $64 \mu \mathrm{g} / \mathrm{mL}$ and final volumes of $50 \mu \mathrm{L}$, plated in duplicate. Then, $50 \mu \mathrm{L}$ of the fungi suspension that was previously prepared in YNB broth to the final concentration of $2.5 \times 10^{3} \mathrm{CFU} / \mathrm{mL}$ were added to each well of the compound-containing plates, giving a final compound concentration range of $0.008-32 \mu \mathrm{g} / \mathrm{mL}$. Plates were covered and incubated at $35{ }^{\circ} \mathrm{C}$ for $36 \mathrm{~h}$ without shaking. C. albicans MICs were determined by measuring the absorbance at $\mathrm{OD}_{530}$. For $\mathrm{C}$. neoformans, resazurin was added at $0.006 \%$ final concentration to each well and incubated for a further $3 \mathrm{~h}$ before MICs were determined by measuring the absorbance at $\mathrm{OD}_{570-600}$.

Colistin and vancomycin were used as positive bacterial inhibitor standards for Gram-negative and Gram-positive bacteria, respectively. Fluconazole was used as a positive fungal inhibitor standard for C. albicans and C. neoformans. The antibiotics were provided in 4 concentrations, with 2 above and 2 below its MIC value, and plated into the first 8 wells of Column 23 of the 384-well NBS plates. The quality control (QC) of the assays was determined by the antimicrobial controls and the $Z^{\prime}$-factor (using positive and negative controls). Each plate was deemed to fulfil the quality criteria (pass QC), if the $\mathrm{Z}$ '-factor was above 0.4 , and the antimicrobial standards showed full range of activity, with full growth inhibition at their highest concentration, and no growth inhibition at their lowest concentration.

\section{Conclusions}

Screening of the ICMP collection in pursuit of novel antimicrobials led to the isolation of a $\gamma$-lactone with a furo[3,4-b]pyran-5-one bicyclic ring system (1), two hydroxymelleins (2 and 3$)$ and an isobenzofuranone (4) from the fungal isolate Microcera larvarum. Upon structure elucidation by NMR, the structure of theissenolactone A (7) was reassigned as $\mathbf{1}$. The absolute configuration of $\mathbf{1}$ was then determined using the chiral derivatizing agent MPA and further supported by a combination of experimental and TDDFT calculated ECD spectroscopy. 
Supplementary Materials: The following are available online. The ${ }^{1} \mathrm{H},{ }^{13} \mathrm{C}, \mathrm{COSY}, \mathrm{HSQC}, \mathrm{HMBC}$ and NOESY NMR spectra and HRESIMS spectrum for compound $\mathbf{1}$ are available along with the calculated relative free energies and specific rotations for the four conformers of $\mathbf{1}$.

Author Contributions: B.R.C. and S.W. conceived, designed and supervised the experiments, analyzed the data and revised the manuscript; M.M.C., S.G. and L.G. performed the experiments and analyzed the data; M.M.C. wrote the initial draft and revised manuscript; and B.S.W. provided resources. All authors have read and agreed to the published version of the manuscript.

Funding: This work was supported by funds from Cure Kids, NZ Carbon Farming, the Maurice Wilkins Centre for Molecular Biodiscovery and donations from the New Zealand public.

Acknowledgments: We would like to thank Michael Schmitz and Tony Chen for their assistance with the NMR and mass spectrometric data and the Community for Antimicrobial Drug Discovery (CO-ADD), funded by the Wellcome Trust (UK) and The University of Queensland (Australia), for carrying out the activity and toxicity testing of the pure compounds. We would also like to thank the New Zealand public for their support of our crowdfunding campaign. S.W. would like to thank Eva, who reminds her why our search for new antibiotics is so important.

Conflicts of Interest: The authors declare no conflict of interest.

\section{References}

1. Gao, X.; Snider, B.B. Syntheses of (-)-TAN-2483A, (-)-Massarilactone B, and the Fusidilactone B Ring System. Revision of the Structures of and Syntheses of ( \pm )-Waol A (FD-211) and ( \pm )-Waol B (FD-212). J. Org. Chem. 2004, 69, 5517-5527. [CrossRef] [PubMed]

2. Liang, W.-L.; Hsiao, C.-J.; Ju, Y.-M.; Lee, L.-H.; Lee, T.-H. Chemical Constituents of the Fermented Broth of the Ascomycete Theissenia cinerea 89091602. Chem. Biodivers. 2011, 8, 2285-2290. [CrossRef] [PubMed]

3. El-Elimat, T.; Figueroa, M.; Raja, H.A.; Adcock, A.F.; Kroll, D.J.; Swanson, S.M.; Wani, M.C.; Pearce, C.J.; Oberlies, N.H. Waol A, trans-dihydrowaol A, and cis-dihydrowaol A: Polyketide-derived $\gamma$-lactones from a Volutella species. Tetrahedron Lett. 2013, 54, 4300-4302. [CrossRef] [PubMed]

4. Latypov, S.K.; Seco, J.M.; Quiñoá, E.; Riguera, R. MTPA vs. MPA in the Determination of the Absolute Configuration of Chiral Alcohols by ${ }^{1}$ H NMR. J. Org. Chem. 1996, 61, 8569-8577. [CrossRef]

5. Rivera-Chávez, J.; Figueroa, M.; González, M.; del, C.; Glenn, A.E.; Mata, R. $\alpha$-Glucosidase Inhibitors from a Xylaria feejeensis Associated with Hintonia latiflora. J. Nat. Prod. 2015, 78, 730-735.

6. Rahman, M.M.; Gray, A.I. A benzoisofuranone derivative and carbazole alkaloids from Murraya koenigii and their antimicrobial activity. Phytochemistry 2005, 66, 1601-1606. [CrossRef] [PubMed]

7. Specimen Details. Available online: https://scd.landcareresearch.co.nz/Specimen/ICMP_5444 (accessed on 15 January 2020).

8. Camarda, L.; Merlini, L.; Nasini, G. Metabolites of Cercospora. Taiwapyrone, an $\alpha$-pyrone of unusual structure from Cercospora taiwanensis. Phytochemistry 1976, 15, 537-539. [CrossRef]

9. Huang, Z.; Ao, F.; Wu, X.; Yang, W.; Huang, T.; Zhang, J.; Zhang, Y. Chemical Constituents of Calotropis gigantea L. and Their Anticancer Activity. Chin. Pharm. J. 2016, 51, 1826-1830.

10. Grimme, S.; Antony, J.; Ehrlich, S.; Krieg, H. A consistent and accurate ab initio parametrization of density functional dispersion correction (DFT-D) for the 94 elements H-Pu. J. Chem. Phys. 2010, 132, 154104. [CrossRef] [PubMed]

11. Grimme, S.; Ehrlich, S.; Goerigk, L. Effect of the damping function in dispersion corrected density functional theory. J. Comput. Chem. 2011, 32, 1456-1465. [CrossRef] [PubMed]

12. Frisch, M.J.; Trucks, G.W.; Schlegel, H.B.; Scuseria, G.E.; Robb, M.A.; Cheeseman, J.R.; Scalmani, G.; Barone, V.; Petersson, G.A.; Nakatsuji, H.; et al. Gaussian 09, Revision D.01; Gaussian, Inc.: Wallingford, CT, USA, 2013.

13. Pescitelli, G.; Bruhn, T. Good Computational Practice in the Assignment of Absolute Configurations by TDDFT Calculations of ECD Spectra: Good Computational Practice. Chirality 2016, 28, 466-474. [CrossRef] [PubMed]

14. Bruhn, T.; Schaumlöffel, A.; Hemberger, Y.; Pescitelli, G. SpecDis Version 1.71, Berlin, Germany. Available online: http://specdis-software.jimdofree.com/ (accessed on 15 January 2020). 
15. Andrews, J.M. Determination of minimum inhibitory concentrations. J. Antimicrob. Chemother. 2001, 48, 5-16. [CrossRef] [PubMed]

16. Blaskovich, M.A.T.; Zuegg, J.; Elliott, A.G.; Cooper, M.A. Helping Chemists Discover New Antibiotics. ACS Infect. Dis. 2015, 1, 285-287. [CrossRef] [PubMed]

Sample Availability: Samples of the compounds are available from the authors.

Publisher's Note: MDPI stays neutral with regard to jurisdictional claims in published maps and institutional affiliations.

(C) 2020 by the authors. Licensee MDPI, Basel, Switzerland. This article is an open access article distributed under the terms and conditions of the Creative Commons Attribution (CC BY) license (http://creativecommons.org/licenses/by/4.0/). 